\title{
Histopathology of Parasellar Neoplasms
}

\author{
Emilija Manojlovic-Gacic ${ }^{a}$ Elham Rostami ${ }^{\text {b,c }}$ Niki Karavitaki ${ }^{\text {d-f }}$ \\ Olivera Casar-Borota ${ }^{g, h}$
}

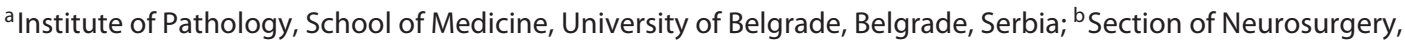
Department of Neuroscience, Uppsala University, Uppsala, Sweden; ' Department of Neuroscience, Karolinska Institute, Stockholm, Sweden; ${ }^{\mathrm{d}}$ Institute of Metabolism and Systems Research, College of

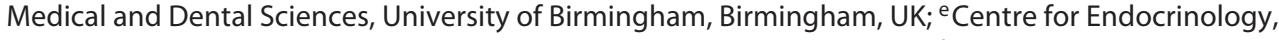
Diabetes and Metabolism, Birmingham Health Partners, Birmingham, UK; ${ }^{\mathrm{f}}$ Department of Endocrinology, Queen Elizabeth Hospital, University Hospitals Birmingham NHS Foundation Trust, Birmingham, UK;

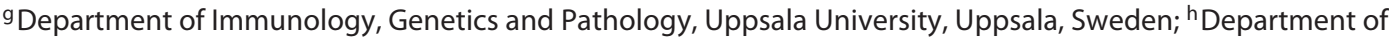
Clinical Pathology, Uppsala University Hospital, Uppsala, Sweden

\section{Keywords}

Parasellar region $\cdot$ Neoplasms $\cdot$ Histopathology

\section{Abstract}

The anatomical and histological complexity of the parasellar region as well as the presence of embryonic remnants determine the huge diversity of parasellar neoplasms. Some of them are only located in the parasellar region, whereas others can occur elsewhere, within or outside the central nervous system. Their spectrum ranges from histologically benign and low-grade malignant to high-grade malignant tumours. Although rare, metastases can pose differential diagnostic dilemmas. The severity of the clinical picture, the challenges of surgery and the risk of adverse sequelae related to surgery or radiotherapy make parasellar tumours interesting entities for the clinicians irrespective of their histological malignancy grade. Due to the different cell origins of parasellar tumours, the World Health Organization classification system does not categorise them as a distinct group. Detailed criteria for classification and malignancy grading are presented in the classification systems covering central nervous system tumours, haematological malignancies and

karger@karger.com www.karger.com/nen Karger"
(C) 2020 The Author(s) Published by S. Karger AG, Basel

Karger Open access

This is an Open Access article licensed under the Creative Commons Attribution-NonCommercial-4.0 International License (CC BY-NC) (http://www.karger.com/Services/OpenAccessLicense), applicable to the online version of the article only. Usage and distribution for commercial purposes requires written permission. tumours of the soft tissue and bone. In the last few years, molecular genetic features have been integrated into the diagnosis of several types of the parasellar tumours enhancing diagnostic accuracy and providing information of the value for targeting therapies. In this review, we will present histopathological and molecular genetic features, updated classification criteria and recent advances in the diagnostics and rationale for novel pharmacological therapies of selected types of parasellar neoplasms.

(c) 2020 The Author(s)

Published by S. Karger AG, Basel

\section{Introduction}

The parasellar region is an anatomically complex area bordering the sella turcica and containing crossroads of many vital structures. The broad landscape of neoplastic lesions in the parasellar region is determined by the presence of numerous and histologically heterogenous structures, as well as of embryonic remnants. With the exception of craniopharyngioma which very rarely arises outside this region, all other parasellar tumours can occur elsewhere, within or outside the central nervous system (CNS).
Olivera Casar-Borota, MD, PhD, Associate Professor

Department of Immunology, Genetics and Pathology, Uppsala University Department of Clinical Pathology, Uppsala University Hospital

Dag Hammarskjölds väg 20, SE-75851 Uppsala (Sweden) olivera.casar-borota@igp.uu.se 
Fig. 1. Anatomical relationships. a Coronal section of the parasellar region. PG, pituitary gland; ICA, internal carotid artery; SS, sphenoid sinus; CS, cavernous sinus; $\mathrm{CN}$, cranial nerve; V1, ophthalmic branch; V2, maxillary branch; NP, nasopharynx; TL, temporal lobe; I, infundibulum. b Inferior view. ACA, anterior cerebral artery; ON, optic nerve; OA, ophthalmic artery; C4OP, cavernous segment of carotid artery, the ophthalmic part; AL, anterior lobe of the pituitary; PL, posterior lobe of the pituitary; TC, tuber cinereum; ACh.A, anterior choroidal artery; PCo. A, posterior communicating artery. c Sagittal section of the parasellar region. BA, basilar artery; C, clivus. Figure 1 is authored by Dr. Elham Rostami.
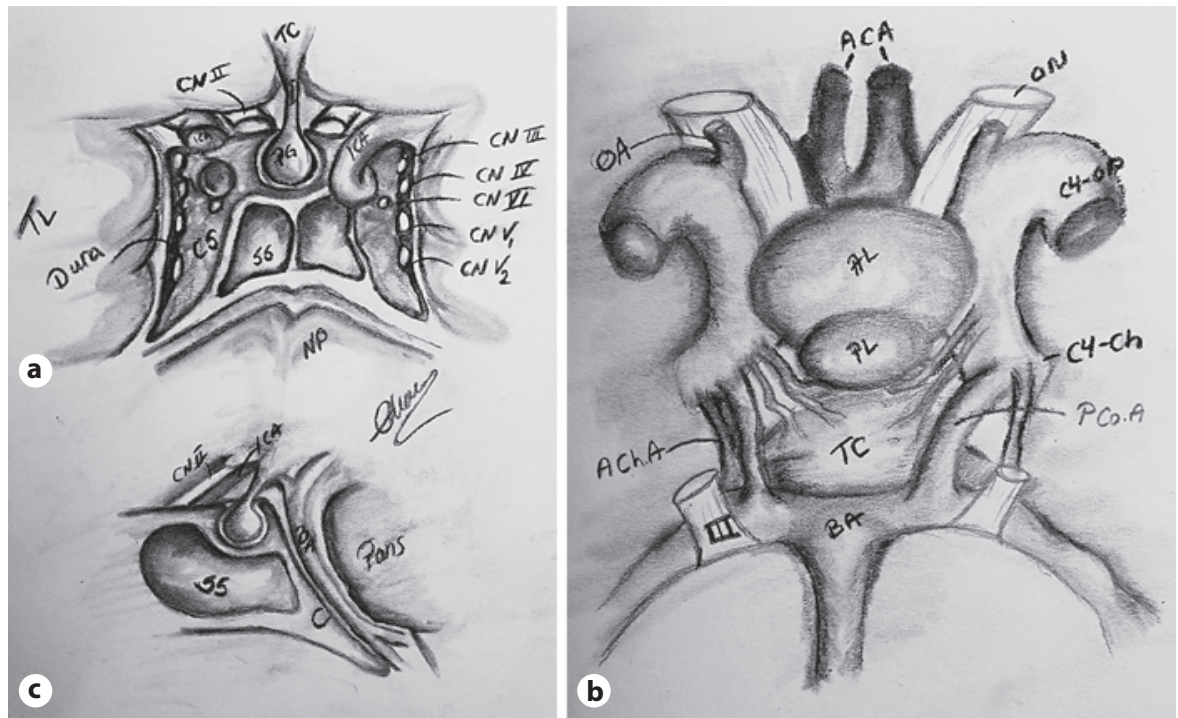

In surgical series, the most frequent neoplasms in the parasellar region are invasive pituitary neuroendocrine tumours. All other neoplasms are rare and comprise about $9 \%$ of the tumours of different cell origin and histological malignancy grade $[1,2]$. Metastases are uncommon but can occur even a long time after the diagnosis of the primary tumour and need to be included in the differential diagnosis $[2,3]$. Originating from different cell types, the parasellar tumours are classified according to the World Health Organization (WHO) classification systems of different organs and tissues [4-7] (Table 1). Parasellar tumours can affect vital anatomical structures, causing a broad spectrum of manifestations, the type and severity of which depend on size, location, biological behaviour of the tumour and age at diagnosis $[1,8,9]$. These complex clinical aspects make the parasellar tumours challenging even when they have benign histological features. Surgery and/or radiotherapy of parasellar tumours can be associated with a high risk of acute and long-term endocrine, neurological, psychological and cognitive complications $[2,10,11]$. This necessitates the introduction of novel pharmacological therapies and definition of the predictive markers.

In this paper, we will summarise the literature covering histopathological and molecular genetic aspects of selected parasellar neoplasms. Given the limitations in the length of this mini review, we will focus on tumours occurring almost exclusively in the parasellar region, those showing a predisposition for the parasellar area and a few tumour types that have only rarely been described in this location. Despite their clinical significance, other lesions usually covered in reviews describing central nervous and soft tissue tumours (e.g., meningiomas) will not be included. Recent advances in the diagnostics and rationales for novel pharmacological therapies will also be presented.

\section{Parasellar Region: Anatomical Considerations}

The sellar region resides at the centre of the cranial base on the sphenoid bone with complex neural and vascular associations. The sella turcica (Turkish saddle) lies in the centre of the sphenoid bone containing the pituitary gland. Anteriorly is the tuberculum sellae and posteriorly the dorsum sellae and clivus. Inferior to the fossa is the sphenoid sinus. Below and behind the sella turcica is the sphenoid sinus that extends posteriorly to the clivus. Above, the sella is covered by the diaphragma sellae as a roof where the infundibulum of the pituitary gland passes through up to the hypothalamus (Fig. 1).

The parasellar region is a part of the middle fossa, between the sella and the temporal fossa. It can be defined as the area surrounding the sella turcica and includes suprasellar cistern, cavernous sinuses, hypothalamus and anterior inferior part of the third ventricle.

The suprasellar cistern is a cerebrospinal fluid-filled space shaped like a pentagon when viewed from above containing the circle of Willis. The infundibulum passes in the centre surrounded anteriorly by the optic chiasm and laterally by the uncus of the temporal lobes.

Cavernous sinuses lie lateral to the pituitary gland where the lateral part of the body of the sphenoid forms 
Table 1. Types of parasellar tumours

\begin{tabular}{|c|c|}
\hline Tissue of the origin & Tumour type \\
\hline $\begin{array}{l}\text { Embryonic remnants of } \\
\text { Rathke's pouch* }\end{array}$ & $\begin{array}{l}\text { Craniopharyngioma* } \\
\text { - Adamantinomatous } \\
\text { - Papillary }\end{array}$ \\
\hline Notochordal remnants* & $\begin{array}{l}\text { Notochordal tumours* } \\
\text { - Benign notochordal cell tumour* } \\
\text { - Chordoma* } \\
\text { O Chordoma NOS } \\
\text { O Chondroid chordoma } \\
\text { O Dedifferentiated chordoma }\end{array}$ \\
\hline Neural crest remnants* & Paraganglioma* \\
\hline Fibroblastic cell* & Solitary fibrous tumour/haemangiopericytoma* \\
\hline Fibroblast/monocyte/osteoclast* & Giant cell tumour of the bone* \\
\hline Germ cells* & $\begin{array}{l}\text { Germinoma* } \\
\text { Yolk sac tumour* } \\
\text { Embryonal cell carcinoma* } \\
\text { Choriocarcinoma* } \\
\text { Teratoma* } \\
\text { Mixed germ cell tumour* }\end{array}$ \\
\hline Lymphocytic neoplasms* & Diffuse large B-cell lymphoma of the CNS* \\
\hline Histiocytic neoplasms* & $\begin{array}{l}\text { Langerhans cell histiocytosis* } \\
\text { Disseminated juvenile xanthogranuloma* } \\
\text { Erdheim-Chester disease* }\end{array}$ \\
\hline Arachnoidea & $\begin{array}{l}\text { Meningioma } \\
\text { Grade I } \\
\text { - Meningothelial } \\
\text { - Fibrous } \\
\text { - Transitional } \\
\text { - Other histological types } \\
\text { Grade II } \\
\text { - Atypical } \\
\text { - Chordoid } \\
\text { - Clear cell } \\
\text { Grade III } \\
\text { - Anaplastic } \\
\text { - Rhabdoid } \\
\text { - Papillary }\end{array}$ \\
\hline Chondroid tissue & $\begin{array}{l}\text { Chondroma } \\
\text { Chondrosarcoma }\end{array}$ \\
\hline Bone & $\begin{array}{l}\text { Osteoma } \\
\text { Osteosarcoma }\end{array}$ \\
\hline Adipose tissue & $\begin{array}{l}\text { Lipoma } \\
\text { Liposarcoma }\end{array}$ \\
\hline Smooth muscle & $\begin{array}{l}\text { Leiomyoma } \\
\text { Leiomyosarcoma }\end{array}$ \\
\hline Striated muscle & Rhabdomyosarcoma \\
\hline Glia* & $\begin{array}{l}\text { Pilocytic astrocytoma* } \\
\text { Pilomyxoid astrocytoma* } \\
\text { Chordoid glioma of the third ventricle* }\end{array}$ \\
\hline Endothelium & Haemangioma \\
\hline Unknown & Atypical teratoid/rhabdoid tumour \\
\hline Schwann cells & $\begin{array}{l}\text { Schwannoma } \\
\text { Malignant peripheral nerve sheet tumour }\end{array}$ \\
\hline
\end{tabular}


the inferior part of the medial wall of the cavernous sinus, extending from the petrous apex to the superior orbital fissure.

The cavernous sinus is encapsulated by two layers of the dura. The oculomotor nerve (cranial nerve, CN III), trochlear nerve (CN IV), ophthalmic $\left(\mathrm{V}_{1}\right)$ and maxillary $\left(\mathrm{V}_{2}\right)$ branches of the trigeminal nerve $(\mathrm{CNV})$ pass through the later wall of the cavernous sinus while the abducens nerve (CN VI) and carotid artery pass through the cavernous sinus.

The parasellar area is considered to be the smallest area of the skull base with the highest concentration of important neural and vascular structures making any neoplasm in this area potentially leading to the neurological deficits with life-threatening complications $[12,13]$.

\section{Craniopharyngioma}

Craniopharyngioma is a histologically benign, although invasively growing, cystic and/or solid tumour originating from the embryonic remnants of Rathke's pouch [4]. This origin was proposed at the beginning of the 20th century based on the histological similarities between Rathke's pouch and craniopharyngiomas [14]. This hypothesis has been further supported by the recent identification of molecular markers of Rathke's pouch precursors in murine and human craniopharyngiomas $[15,16]$. Craniopharyngiomas are almost exclusively located in the sellar and suprasellar regions [17]. The cerebellopontine angle is the most frequent location among uncommon cases of extrasellar craniopharyngiomas [18].

Craniopharyngioma occurs in two morphologically distinct variants. Adamantinomatous craniopharyngioma (ACP) is composed of squamous epithelium with focally looser "stellate reticulum," palisading of the basal cells and accumulation of degenerative, "wet keratin" [4] (Fig. 2a). Papillary craniopharyngioma (PCP) consists of non-keratinising squamous epithelium covering papillary fibrovascular cores [4] (Fig. 2d). Rarely, ACP and PCP coexist in the same lesion $[19,20]$. ACP is the predominant subtype in childhood onset disease but may develop at all ages, whereas PCP is almost exclusively found in adults [4]. Craniopharyngioma has a distinct microscopic morphology. Differential diagnostic difficulties associated with other epithelial tumours (e.g., metastases) that can be rarely encountered in cases with sparse pathological material, are usually resolved by a multidisciplinary approach correlating histopathology, MRI find-

Histopathology of Parasellar Neoplasms ings and clinical characteristics, such as patient age or history of malignancy in other organs.

The molecular mechanisms behind the two histological variants of craniopharyngiomas have recently been clarified. ACP is characterised by mutations in the CTN$N B 1$ gene, encoding $\beta$-catenin, which subsequently lead to aberrant nuclear translocation of this protein as demonstrated by immunohistochemistry in a subset of tumour cells forming epithelial whorls [21] (Fig. 2c). Nearly all PCPs are driven by a BRAFV600E mutation that constitutively activates the MAPK/ERK signalling pathway [22]. Mutated BRAFV600E is expressed in epithelial neoplastic cells and can be demonstrated by using a monoclonal VE1 antibody (Fig. 2e) [23]. However, positive immunolabelling with the VE1 antibody without detectable BRAFV600E mutation has been demonstrated in the anterior pituitary gland, other endocrine organs and a subset of pituitary neuroendocrine tumours [24, 25]. Therefore, confirmation of the mutation by genetic analysis is recommended, particularly in patients who are candidates for BRAF-targeting therapy.

BRAFV600E inhibitors alone or in combination with MAPK/ERK inhibitors have been successfully used recently in PCPs [26-31]. On the other hand, drugs targeting $\beta$-catenin and its downstream MAPK pathway have been used only in in vitro studies, and their value in the management of ACP requires assessment in a clinical trial $[32,33]$. Recently, the programmed cell death protein 1 and programmed cell ligand-1 (PD-1/PD-L1) have been demonstrated in epithelial neoplastic cells and immune cells of both ACP and PCP $[34,35]$ opening a new possible avenue for immune-mediating therapy of craniopharyngiomas.

\section{Chordoma}

Chordomas are malignant tumours arising from the embryonic notochordal remnants typically affecting the most extreme part of the axial skeleton, clivus and lumbosacral vertebral column. They are surgically challenging to remove and may metastasise in up to $40 \%$ of cases, more commonly the spinal than the skull base chordomas [7]. Chordomas are composed of large, vacuolated "physaliphorous cells" frequently growing in a trabecular pattern surrounded by a myxoid matrix (Fig. 3a, b) [7]. Similar to the embryonic notochord, the neoplastic cells of chordoma express both epithelial (cytokeratin) and neuronal (S-100 protein) markers, as well as brachyury, a Tgene encoded transcription factor that plays a pivotal role 

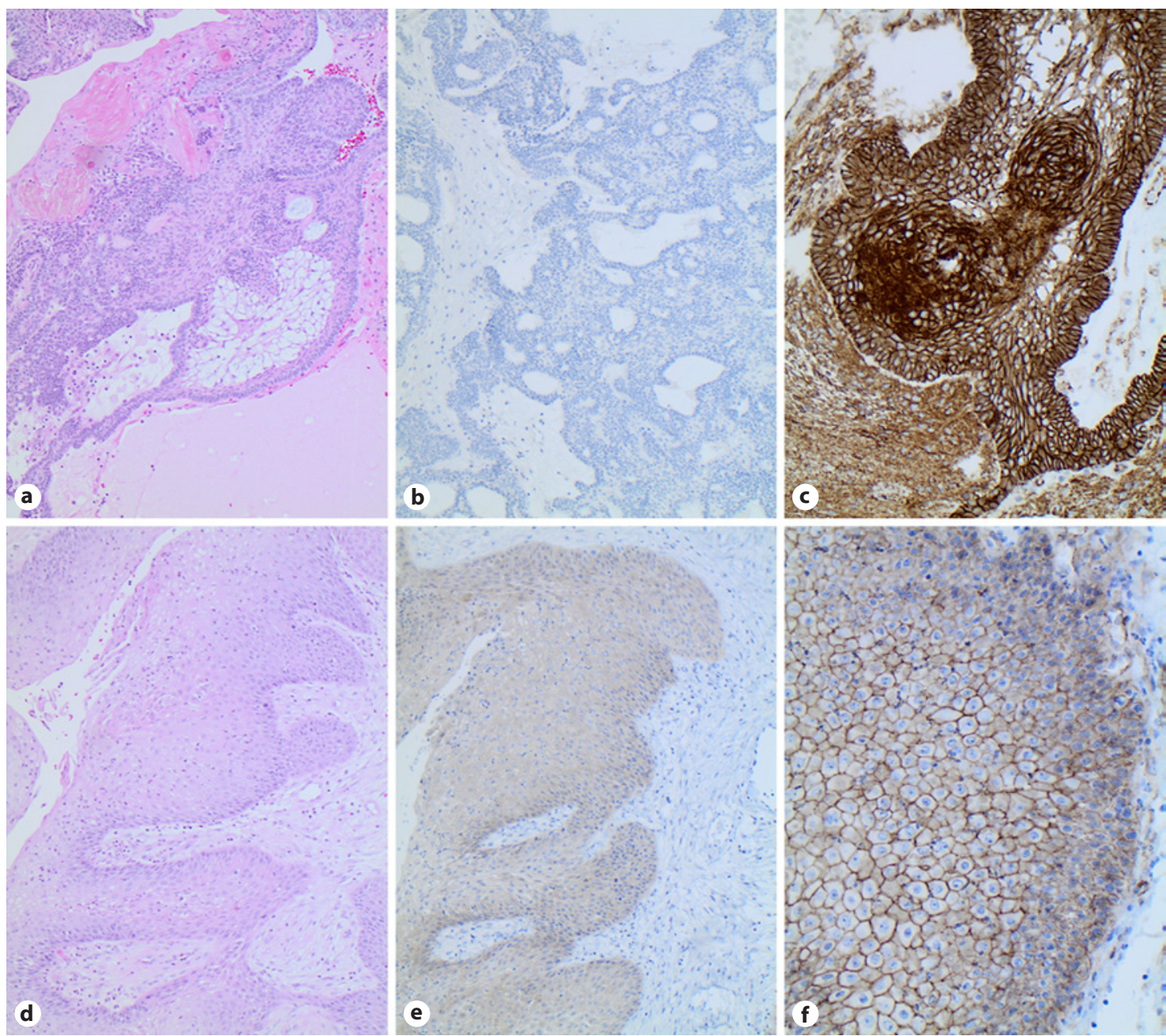

Fig. 2. Craniopharyngioma. Adamantinomatous type (upper row) characterised by: typical epithelial features with "wet keratin" and "stellate reticulum" (a, HE, $\times 100)$; lack of BRAFV600E immunolabelling (b, $\times 100)$; a nuclear translocation of $\beta$-catenin in tumour cells forming epithelial whorls $(\mathbf{c}, \times 200)$. Papillary craniopharyngioma (lower row) characterised by: papillary projections of non-keratinising squamous epithelium (d, HE, $\times 100)$; expression of BRAFV600E $(\mathbf{e}, \times 100)$ and membranous $\beta$-catenin positivity $(\mathbf{f}, \times 200)$.

in the notochord differentiation (Fig. 3c-e) [36, 37]. Although rarely expressed in other tumours, brachyury is a specific marker valuable in the pathological differentiation of chordoma from chondroma, chondrosarcoma, chordoid meningioma and carcinomas [38]. Germline duplications of $\mathrm{T}$ gene encoding brachyury are associated with familial predisposition to chordoma [39].

Apart from the most frequent conventional chordoma or chordoma not otherwise specified, the WHO classification defines two additional rare subtypes [7], the chondroid chordoma and the dedifferentiated chordoma. In chondroid chordoma, the myxoid matrix resembles hyaline cartilaginous tumour. This subtype has no prognos- tic value but needs to be discriminated from chondroma and chondrosarcoma based on morphology, brachyury expression in chordoma and evidence of isocitrate dehydrogenase 1 or 2 (IDH1/2) mutations in a subset of chondromas and chondrosarcomas [40]. Dedifferentiated chordoma is a biphasic tumour with a conventional brachyury-positive chordoma component and a dedifferentiated, spindle cell sarcoma component which has loss of brachyury [7]. In 5 out of 6 recently reviewed cases, this high-grade malignant subtype developed through dedifferentiation secondary to radiotherapy or after incomplete surgical removal of a conventional chordoma [41]. Not included in the current WHO classification is a rare 


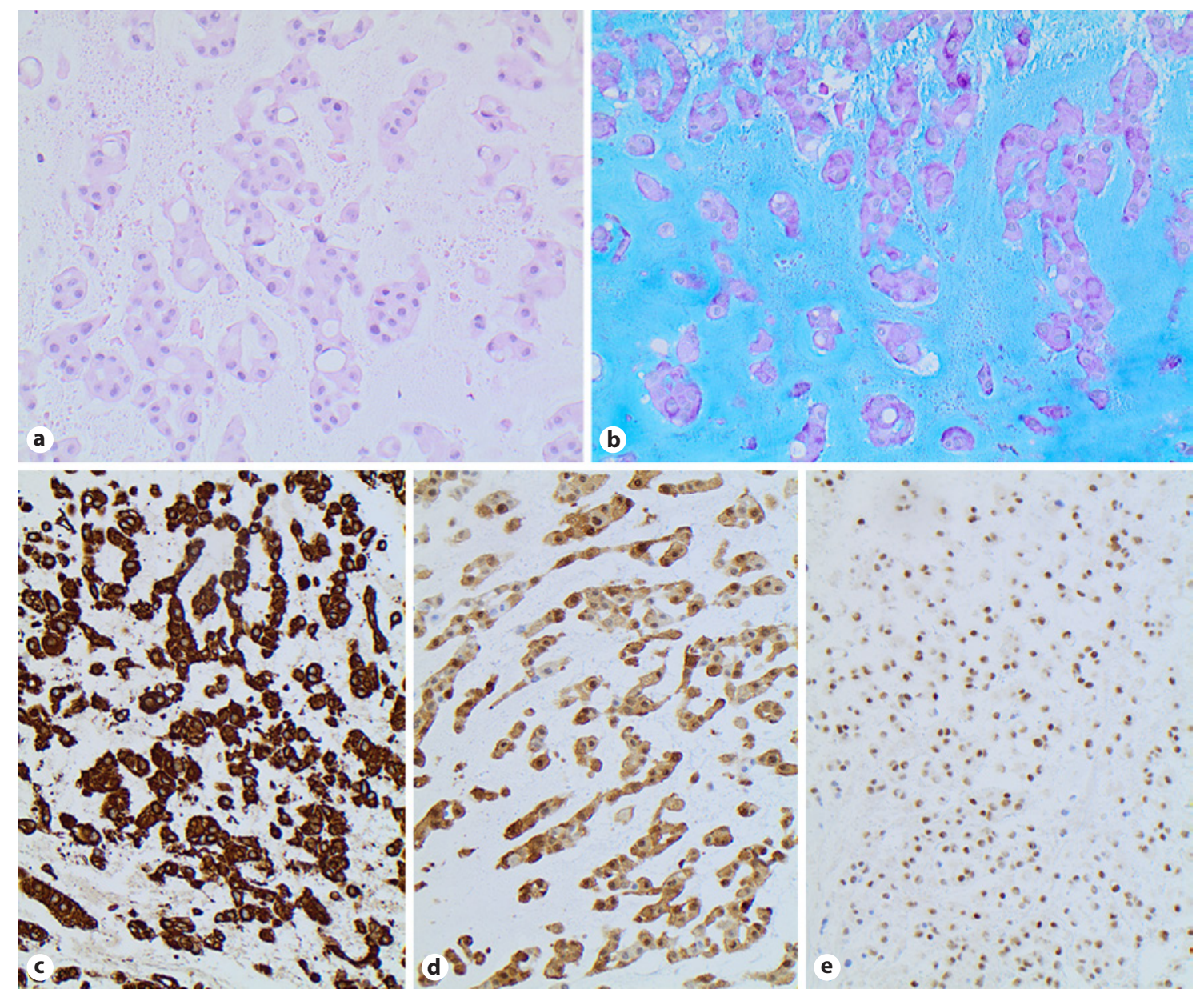

Fig. 3. Chordoma not otherwise specified demonstrating "physaliphorous" tumour cells arranged in trabecules $(\mathbf{a}, \mathrm{HE}, \times 200)$, rich myxoid matrix surrounding the tumour cells (b, Alcian blue/PAS, $\times 200)$, cytokeratin AE1/ AE3 (c, $\times 200)$, S-100 (d, $\times 200)$ and nuclear brachyury expression $(\mathbf{e}, \times 200)$.

paediatric poorly differentiated chordoma of the clivus characterised by loss of SMARCB1 (INI1) and poor prognosis $[42,43]$. Brachyury expression is valuable to differentiate this variant from INI1-negative atypical teratoid rhabdoid tumour that has exceptionally been reported in the sellar region [42, 44-46].

Benign notochordal cell tumour has a very indolent course and should not be misdiagnosed as a chordoma. It is composed of adipocyte-like, brachyury-positive cells and lacks a myxoid matrix. Despite occasional coexistence in the same lesion, there is no evidence that benign notochordal cell tumour is a precursor of chordoma [7, 47-49].

Mutations in the PI3K/AKT/TSC1/TSC2/mTOR signalling pathway in chordomas could be potential targets of mTOR inhibitors [50]. Nonetheless, current data suggest suboptimal response to these agents [51]. Furthermore, initial results with immune-check point inhibitors and brachyury-targeting therapy have not been encouraging [52]. Tazemetostat, an inhibitor of EZH2 protein which is upregulated in tumours characterised by SMARCB1 loss, is under a clinical trial and has shown promising results in paediatric patients with poorly differentiated chordomas [51].

\section{Paraganglioma}

Paragangliomas are neuroendocrine neoplasms, usually encapsulated and benign. It is postulated that they arise from remnant neural crest cells which are diffusely dispersed or are associated with segmental or collateral autonomic ganglia (paraganglia). In the CNS, paragangliomas primarily affect the cauda equina/filum terminale and jugulotympanic regions [4]. Less than 20 cases 

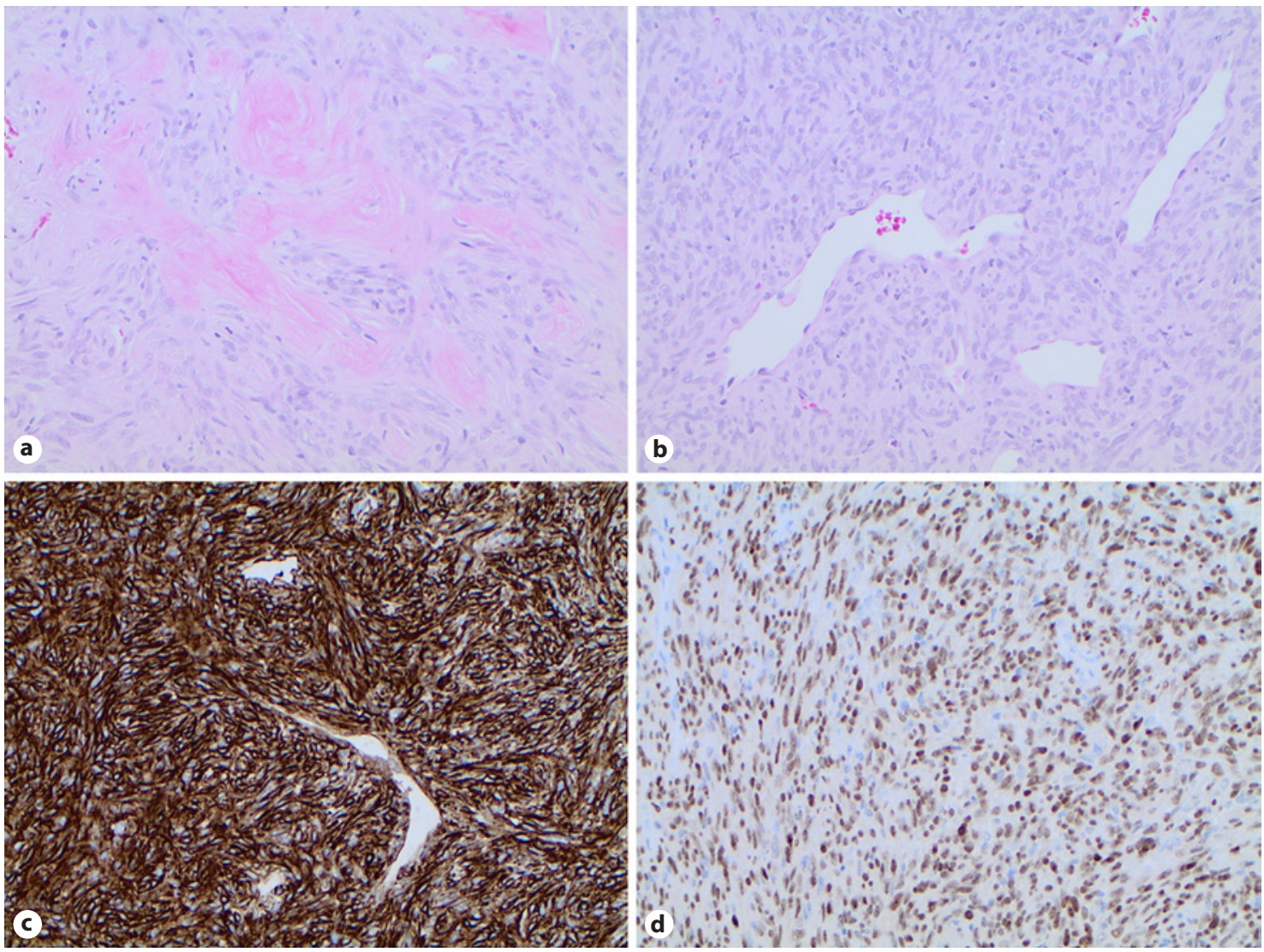

Fig. 4. Haemangiopericytoma/solitary fibrous tumour. a Solitary fibrous tumour phenotype characterised by spindle cells arranged in fascicles separated by thick collagenous bands. HE, $\times 200$. b Haemangiopericytoma phenotype with haphazard growth pattern of cells with round to ovoid nuclei and thin-walled branching vessels. HE, $\times 200$. c, d CD34 expression $(\mathbf{c}, \times 200)$ and nuclear expression of STAT6 $(\mathbf{d}, \times 200)$.

of primary sellar/parasellar paraganglioma have been reported and recently reviewed; none of them had evidence of catecholamine secretion $[53,54]$.

Although classified as histologically benign WHO grade I tumours, paragangliomas may demonstrate invasive growth and in up to $20 \%$ of cases, there are even distant metastases [4]. Distant metastases have not been reported as yet in parasellar paragangliomas [53]. Genetic analysis for identifying familiar cases is needed, and its results will determine further monitoring.

Histologically, paragangliomas are composed of synaptophysin- and chromogranin A-positive neuroendocrine chief cells that form a typical lobular, "zellballen" pattern emphasised by peripheral S-100- and glial fibrillary acidic protein-immunolabelled sustentacular cells. Expression of cytokeratin may vary and be absent in primary sellar paragangliomas [53]. Mitotic figures and necrosis are rare [4]. There are no histological parameters reliably predicting the risk for invasive growth or meta- static potential. In cases without typical morphology, positive immunolabelling for tyrosine hydroxylase and lack of organ-specific transcription factors can be helpful to differentiate paraganglioma from pituitary neuroendocrine tumours or metastases of neuroendocrine tumours from other locations.

Up to $50 \%$ of adult paragangliomas and more than $80 \%$ of paediatric ones are associated with germline mutations [4], most frequently in one of the succinate dehydrogenase (SDH) genes: $S D H A, S D H B, S D H C, S D H D$, SDHAF2 [55-59]. In addition to family history, early onset, multiple tumour occurrence and association with non-paraganglial tumours should raise suspicion for genetic predisposition [60]. Immunohistochemistry on sections from formalin-fixed paraffin-embedded tissue is a reliable method to detect SDHx mutations [61, 62], with loss of SDHB revealing mutations in different $S D H$ genes [61]. Recently, somatic ATRX mutations, which can be suspected on the basis of the lack of ATRX in the tumour 

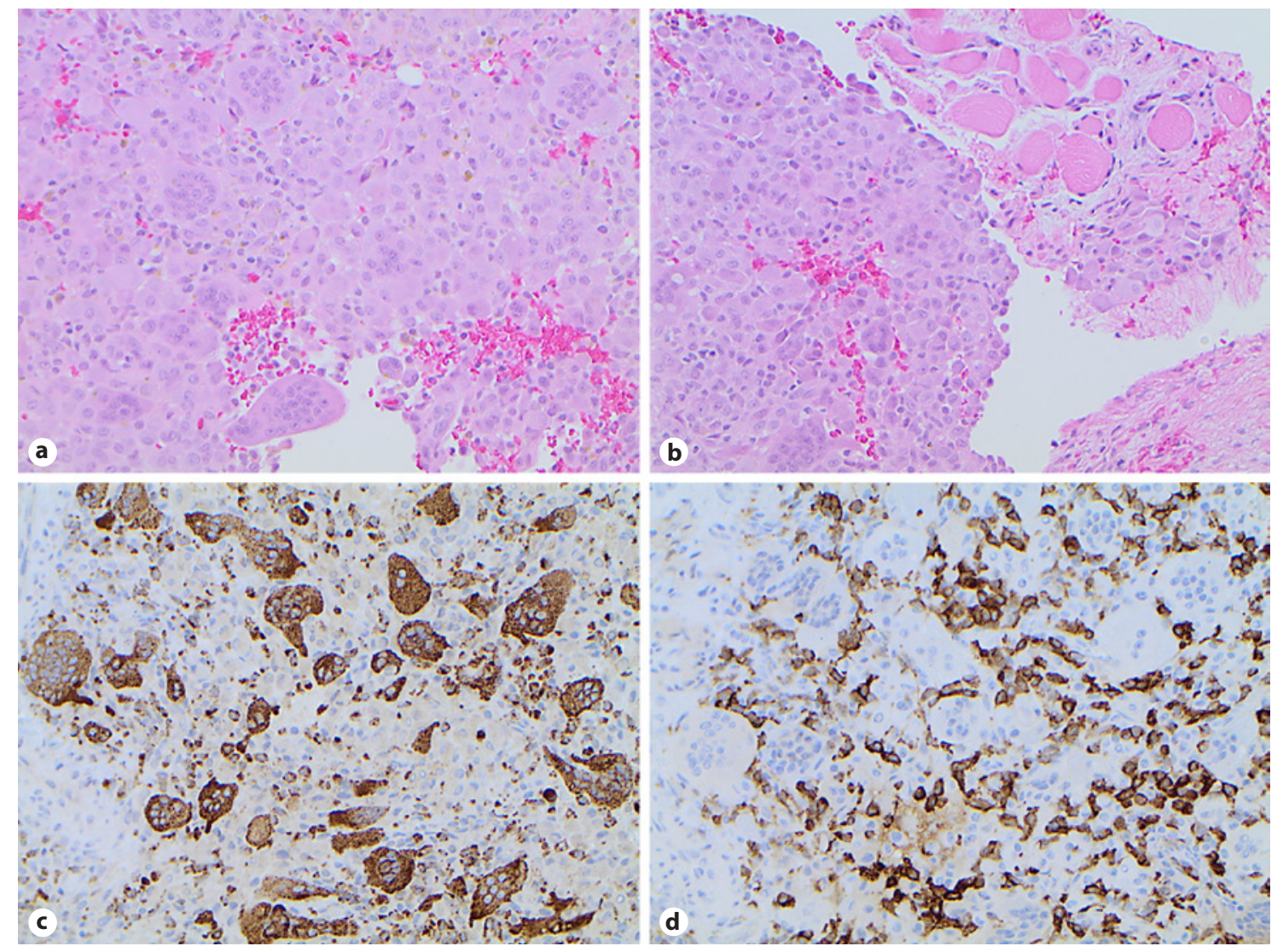

Fig. 5. Giant cell tumour of the bone. a Neoplastic mononuclear cells admixed with macrophages and osteoclastlike giant cells. HE, $\times 200$. b Tumour cells infiltrating extracranial muscle. HE, $\times 200$. c CD68-positive reactive cells. $\times 400$. d CD163 immunolabelling of neoplastic cells. $\times 400$.

cells, have been reported and strongly associated with a risk for metastatic paragangliomas [63, 64]. Somatic mutations in isocitrate dehydrogenase are extremely uncommon in paragangliomas [65] and can coexist with ATRX mutations [66].

\section{Haemangiopericytoma/Solitary Fibrous Tumour}

Haemangiopericytoma is a mesenchymal tumour of fibroblastic type. It represents a histological spectrum of neoplasms previously classified separately as meningeal solitary fibrous tumour (SFT) and haemangiopericytoma (HPC) [4]. In the CNS, HPC and SFT are usually, but not always, connected to the cranial or spinal dura [67]. The sellar/parasellar region is an uncommon location with less than 20 cases reported until now in sporadic case reports that are seldomly comprehensively reviewed [68].

A distinct molecular feature unifying SFT and HPC into one group is a fusion of NAB2 and STAT6 genes [4,
$69,70]$ which results in nuclear translocation of STAT6 protein; this can be detected by immunohistochemistry and represents a key diagnostic feature of SFT/HPC [71]. Nuclear STAT6 expression is also a useful marker for the differential diagnosis towards fibrous meningioma or sellar schwannoma that can be particularly challenging when the surgical material is sparse and the morphology not typical.

Morphologically, SFTs are tumours composed of spindle cells growing in fascicles separated by thick collagenous bands. HPCs are characterised by haphazard arrangement of cells with spindle-shaped to oval nuclei surrounded by a rich and delicate reticulin network and characteristic staghorn vascular pattern. Both morphological types, besides nuclear STAT6 positivity, express typically vimentin and CD34 (Fig. 4) [4]. Several studies indicate that the morphological phenotype depends on the type of NAB2/STAT6 fusion [72-75].

SFT is a benign WHO grade I tumour, whereas the HPC phenotype demonstrates more aggressive behav- 

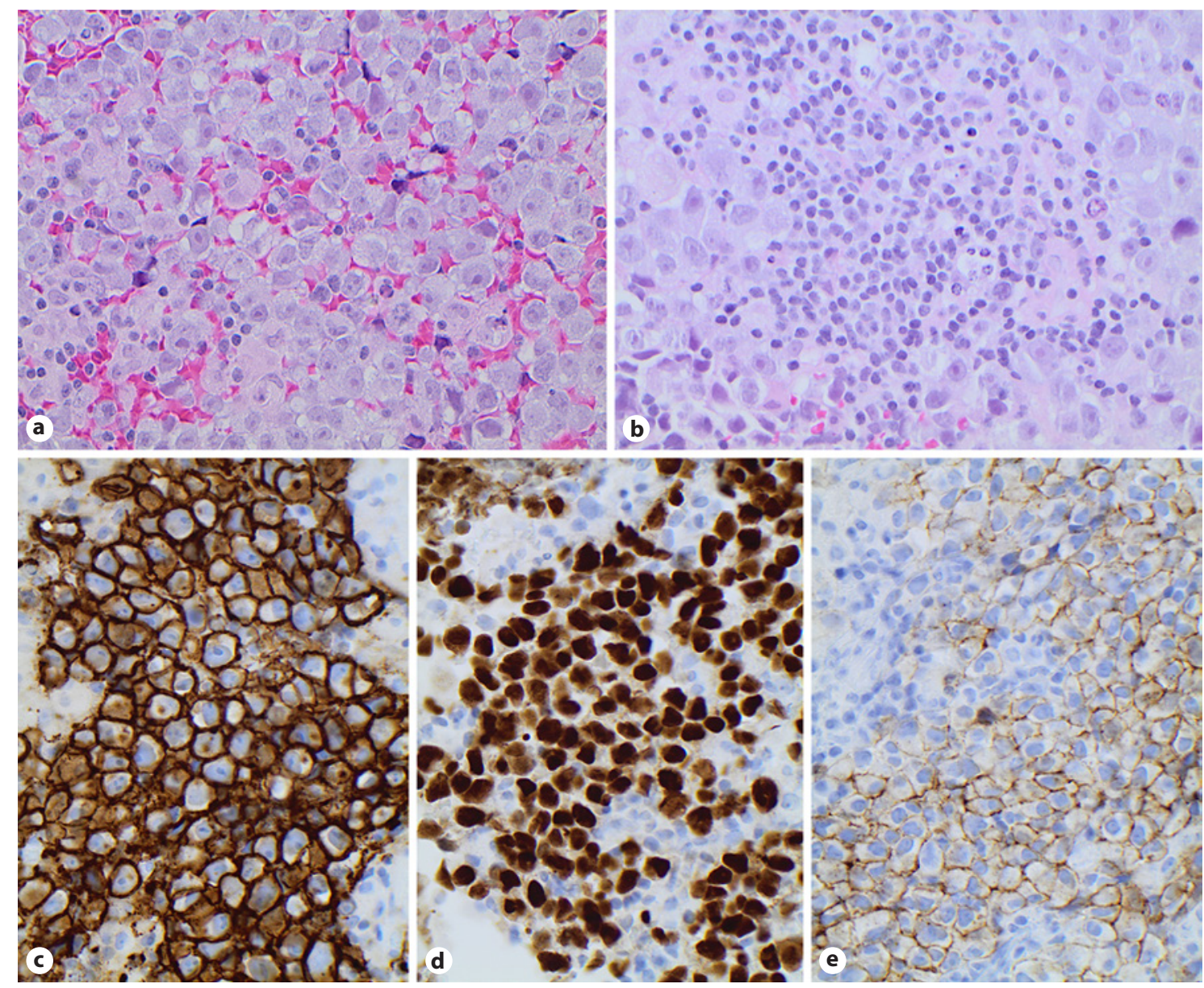

Fig. 6. Germinoma characterised by: sheets of uniform rounded cells with clear cytoplasm (a, HE, $\times 400)$; focal lymphocytic infiltration (b, HE, $\times 400)$; membranous D2-40 expression $(\mathbf{c}, \times 400)$; nuclear Oct 3/4 (d, $\times 400)$ and membranous CD117 (e, $\times 400)$ immunolabelling.

iour with a relatively high rate of recurrence and risk of metastasis giving ground to its higher malignancy grade compared to the SFT. The single histological criterion to differentiate between WHO grade II and grade III HPC is the mitotic count with a cut-off level of 5 mitoses per 10 high-power field [4]. In a recent study, a three-tiered system including both mitotic count and necrosis seemed to provide the most accurate prognostic stratification within this tumour family [75].

\section{Giant Cell Tumour of Bone}

Giant cell tumour (GCT) of bone is a benign but locally aggressive primary bone neoplasm that typically affects the epiphyses of long bones. In uncommon cases of skull involvement, GCT shows a predilection for tempo- ral and sphenoid bone [76]. Rare primary malignancies and malignancy secondary to radiotherapy in GCT [77, 78] could be, at least partially, explained by p 53 mutations $[79,80]$.

Histologically, the GCT is composed of a proliferation of neoplastic mononuclear cells admixed with numerous macrophages and large reactive osteoclast-like giant cells. The neoplastic cells express CD163, a macrophage and monocyte activation marker, and lack CD68, a classical macrophage marker expressed in reactive macrophages and osteoclast-like giant cells of the GCT [7] (Fig. 5). More than $90 \%$ of GCTs are characterised by a distinct H3.3 histone mutation in H3F3A [81] which is used for the differentiation from the other giant cell, osteoclastrich bone tumours and chondroblastomas, especially in scarce fine-needle biopsy specimens $[82,83]$. Due to decalcification protocols applied to the bone tumour speci- 
mens, molecular pyrosequencing-based techniques seem to be more reliable than immunohistochemistry in the identification of $H 3 F 3 A$ mutations [84].

\section{Germ Cell Tumours}

Intracranial germ cell tumours arise along the cranial midline axis, slightly less frequently in the suprasellar than in the pineal region, with predilection for children and young adult males [4]. Simultaneous occurrence of suprasellar and pineal germ cell tumour has been designated as "bifocal germ cell tumour" [85]. The germ cell tumours, except benign teratomas, are malignant and can easily metastasise through the cerebrospinal fluid, e.g. "drop metastases." In the CNS, germ cell tumours represent the morphological, immunophenotypic and genetic homologues of gonadal and other extraneuraxial germ cell neoplasms [4]. The histogenesis of these tumours in the CNS is unclear. An origin from the primordial germ cells remaining in the neuraxial midline due to aberrant migration to the gonadal ridges or from the native neural stem cells of embryonic pluripotent type has been suggested [86-89]. A significantly higher incidence in eastern Asia which persists even in ancestries settled in the other parts of the world suggests the implication of genetic factors $[4,90]$.

The WHO classification system recognises 5 histological types of germ cell tumours: germinomas, embryonal carcinoma, yolk-sac tumour, choriocarcinoma and teratoma. Mixed types with the presence of different tumour components are not uncommon [4]. Germ cell tumours can be divided into two risk groups: germinomas and non-germinomas, with significantly better prognosis after radio- and chemotherapy for the former group [91]. The most frequent subtype, germinoma is characterised by sheets of rounded CD117, D2-40, OCT4 and NANOGpositive cells surrounded by lymphocytes, dominantly of T-cell phenotype (Fig. 6). Lymphocytic infiltration, sometimes with formation of germinal centres, can mask the typical morphology and represent a challenging differential diagnosis versus chronic inflammatory lesion or haematological malignancies, especially in scarce specimens. In such cases, a detailed clinical, radiological and pathological correlation is highly recommended. Other histological subtypes are very rare in the CNS as a primary location and show the histological pattern seen in the gonadal presentation.

Recent molecular investigations of germ cell tumours revealed mutations in the MAPK pathway frequently as- sociated with male gender [91]. Recurrent mutations in the mTOR pathway in intracranial germ cell tumours have emerged as potential therapeutic targets [92]. Rich lymphocytic infiltration in germinomas and expression of PD-1 and PDL- 1 on the inflammatory cells within germinomas may potentially be targeted by immune check point inhibitors [93].

\section{Haematopoietic and Lymphoid Tumours}

Even though lymphomas and histiocytic cell neoplasms are rarely observed in the CNS, as a solitary lesion or in the form of the disseminated disease, the parasellar region could also be affected.

Similarly, to the CNS lymphomas in general, rare parasellar lymphomas belong to diffuse large B-cell lymphomas [94].

Several types of histiocytic disorders, such as Langerhans cell histiocytosis, disseminated juvenile xanthogranuloma and Erdheim-Chester disease, may have predilection for the parasellar region. Morphological, immunohistochemical and molecular genetic features of these tumours are in detail presented elsewhere [6]. Although considered as reactive in the past, the majority of histiocytic lesions in the CNS including the parasellar region represent true monoclonal neoplasms [6] that need to be differentiated from the secondary inflammatory lesions [95].

\section{Glial Tumours}

Even though glial tumours of all types could be localised in the parasellar space, pilocytic astrocytoma, pilomyxoid astrocytoma and chordoid glioma of the third ventricle show predilection for this region [4]. These can be differentiated from other tumour types based on their morphology and on the expression of glial fibrillary acidic protein that confirms the glial origin of the tumour cells.

The optic tract and hypothalamus comprise preferable supratentorial location for pilocytic astrocytoma. Pilocytic astrocytoma involving the optic nerve is a hallmark of neurofibromatosis type 1 [4]. A majority of pilocytic astrocytomas contain a KIAA1549-BRAF fusion gene [96]. $B R A F V 600 E$ mutation is, however, associated with extracerebellar tumour location in a subset of patients [97]. Although in general slowly growing tumours corresponding to WHO grade 1, pilocytic astrocytomas in parasellar 
location may not be amenable to gross total resection, which increases a risk of recurrence and progress [4].

Pilomyxoid astrocytoma is a variant of pilocytic astrocytoma of uncertain malignancy grade preferentially affecting the hypothalamic/chiasmatic region in young children [4].

Chordoid glioma of the third ventricle is a rare, WHO grade II neoplasm of adult patients with favourable prognosis when totally resected [4]. However, the tumour is mostly attached or invades the hypothalamus; consequently, only subtotal resection has been reported. A recent study defined PRKCA mutation as a recurrently mutated oncogene in pilomyxoid astrocytoma, which may have potential therapeutic implications [98].

\section{Conclusion}

A wide heterogeneity of parasellar neoplasms demands a huge experience in neuropathology in order to cover this fascinating field and avoid pitfalls in histopath- ological diagnostics. Integration of the molecular genetic mechanisms in the evolving WHO tumour classification increases diagnostic accuracy and enables new targeted pharmacotherapies giving hope for an optimised impact on the patients' prognosis and outcome. A multidisciplinary approach is required in order to overcome challenges in the diagnostics and treatment of patients with parasellar neoplasms.

\section{Disclosure Statement}

The authors have no conflicts of interest to declare.

\section{Author Contributions}

Olivera Casar-Borota recommended the structure of the paper and prepared the final version. Emilija Manojlovic-Gacic wrote the first draft. Elham Rostami contributed with the anatomy section, Figure 1 and clinical comments. Niki Karavitaki contributed with clinical comments and discussions. All the authors read, edited and approved the final paper.

\section{References}

1 Freda PU, Wardlaw SL, Post KD. Unusual causes of sellar/parasellar masses in a large transsphenoidal surgical series. J Clin Endocrinol Metab. 1996 Oct;81(10):3455-9.

2 Barkhoudarian G, Zada G, Laws ER. Endoscopic endonasal surgery for nonadenomatous sellar/parasellar lesions. World Neurosurg. 2014 Dec;82(6 Suppl):S138-46.

3 Schill F, Nilsson M, Olsson DS, Ragnarsson O, Berinder K, Edén Engström B, et al. Pituitary Metastases: A Nationwide Study on Current Characteristics With Special Reference to Breast Cancer. J Clin Endocrinol Metab. 2019 Aug;104(8):3379-88.

4 Louis DN, Ohgaki H, Wiestler OD, Cavenee WK. World Health Organization Classification of Tumours of the Central Nervous System. Revised. 4th ed. Lyon: IARC Press; 2016.

5 Lloyd RV, Osamura RY, Kloppel G, Rosai J. World Health Organization classification of tumours of endocrine organs. 4th ed. Lyon: IARC Press; 2017.

6 Swerdlow SH, Campo E, Harris NL, Jaffe ES, Pileri SA, Stein H, et al. WHO Classification of Tumours of Haematopoietic and Lymphoid Tissues. Revised 4th edn. Lyon: IARC Press; 2017.

7 Fletcher CD, Bridge JA, Hogendoorn PC, Mertens F. WHO Classification of Tumours of Soft Tissue and Bone. 4th ed. Lyon: IARC Press; 2013.

8 Fjalldal S, Holmer H, Rylander L, Elfving M, Ekman B, Osterberg K, et al. Hypothalamic involvement predicts cognitive performance and psychosocial health in long-term survivors of childhood craniopharyngioma. J Clin Endocrinol Metab. 2013 Aug;98(8):3253-62.

9 Unsinn C, Neidert MC, Burkhardt JK, Holzmann D, Grotzer M, Bozinov O. Sellar and parasellar lesions - clinical outcome in 61 children. Clin Neurol Neurosurg. 2014 Aug;123: 102-8.

10 Sheehan JP, Starke RM, Kano H, Kaufmann AM, Mathieu D, Zeiler FA, et al. Gamma Knife radiosurgery for sellar and parasellar meningiomas: a multicenter study. J Neurosurg. 2014 Jun;120(6):1268-77.

11 Nagata Y, Watanabe T, Nagatani T, Takeuchi $\mathrm{K}$, Chu J, Wakabayashi T. Fully endoscopic combined transsphenoidal and supraorbital keyhole approach for parasellar lesions. J Neurosurg. 2018 Mar;128(3):685-94.

12 Rhoton AL Jr. The sellar region. Neurosurgery. 2002 Oct;51(4 Suppl):S335-74.

13 Martins C, Yasuda A, Campero A, de Alencastro LF, Inoue K, Rhoton AL Jr. Microsurgical and Endoscopic Anatomy of the Parasellar Region. In: Stamm AC, editor. Transnasal Endoscopic Skull Base and Brain Surgery, Tips and Pearls. 1st ed. New York: Thieme; 2011. pp. 211-23.

14 Erdheim J. Über Hypophysengangsgeschwülste und Hirncholesteatome. Sitz Kais Akad Wissen Math Naturw Klin. 1904;113:537726.

15 Gaston-Massuet C, Andoniadou CL, Signore M, Jayakody SA, Charolidi N, Kyeyune R, et al. Increased Wingless (Wnt) signaling in pitu- itary progenitor/stem cells gives rise to pituitary tumors in mice and humans. Proc Natl Acad Sci USA. 2011 Jul;108(28):11482-7.

16 Andoniadou CL, Gaston-Massuet C, Reddy R, Schneider RP, Blasco MA, Le Tissier P, et al. Identification of novel pathways involved in the pathogenesis of human adamantinomatous craniopharyngioma. Acta Neuropathol. 2012 Aug;124(2):259-71.

17 Karavitaki N, Cudlip S, Adams CB, Wass JA. Craniopharyngiomas. Endocr Rev. 2006 Jun; 27(4):371-97.

18 Gabel BC, Cleary DR, Martin JR, Khan U, Snyder V, Sang UH. Unusual and rare locations for craniopharyngiomas: clinical significance and review of the literature. World Neurosurg. 2017 Feb;98:381-7.

19 Okada T, Fujitsu K, Ichikawa T, Mukaihara S, Miyahara K, Kaku S, et al. Coexistence of adamantinomatous and squamous-papillary type craniopharyngioma: case report and discussion of etiology and pathology. Neuropathology. 2012 Apr;32(2):171-3.

20 Larkin SJ, Preda V, Karavitaki N, Grossman A, Ansorge O. BRAF V600E mutations are characteristic for papillary craniopharyngioma and may coexist with CTNNB1-mutated adamantinomatous craniopharyngioma. Acta Neuropathol. 2014;127(6):927-9.

21 Sekine S, Shibata T, Kokubu A, Morishita Y, Noguchi M, Nakanishi Y, et al. Craniopharyngiomas of adamantinomatous type harbor beta-catenin gene mutations. Am J Pathol. 2002 Dec;161(6):1997-2001. 
22 Brastianos PK, Taylor-Weiner A, Manley PE, Jones RT, Dias-Santagata D, Thorner AR, et al. Exome sequencing identifies BRAF mutations in papillary craniopharyngiomas. Nat Genet. 2014 Feb;46(2):161-5.

23 Capper D, Preusser M, Habel A, Sahm F, Ackermann U, Schindler G, et al. Assessment of BRAF V600E mutation status by immunohistochemistry with a mutation-specific monoclonal antibody. Acta Neuropathol. 2011 Jul;122(1):11-9.

24 Mordes DA, Lynch K, Campbell S, Dias-Santagata D, Nose V, Louis DN, et al. VE1 antibody immunoreactivity in normal anterior pituitary and adrenal cortex without detectable BRAF V600E mutations. Am J Clin Pathol. 2014 Jun;141(6):811-5.

25 Sperveslage J, Gierke M, Capper D, Honegger J, Sipos B, Beschorner R, et al. VE1 immunohistochemistry in pituitary adenomas is not associated with BRAF V600E mutation. Acta Neuropathol. 2013 Jun;125(6):911-2.

26 Brastianos PK, Shankar GM, Gill CM, TaylorWeiner A, Nayyar N, Panka DJ, et al. Dramatic Response of BRAF V600E Mutant Papillary Craniopharyngioma to Targeted Therapy. J Natl Cancer Inst. 2015 Oct;108(2):djv310.

27 Aylwin SJ, Bodi I, Beaney R. Pronounced response of papillary craniopharyngioma to treatment with vemurafenib, a BRAF inhibitor. Pituitary. 2016 Oct;19(5):544-6.

28 Rostami E, Witt Nyström P, Libard S, Wikström J, Casar-Borota O, Gudjonsson O. Recurrent papillary craniopharyngioma with BRAFV600E mutation treated with neoadjuvant-targeted therapy. Acta Neurochir (Wien) 2017 Nov; 159(11):2217-21.

29 Rao M, Bhattacharjee M, Shepard S, Hsu S. Newly diagnosed papillary craniopharyngioma with BRAF V600E mutation treated with single-agent selective BRAF inhibitor dabrafenib: a case report. Oncotarget. 2019 Oct 10(57):6038-42.

30 Juratli TA, Jones PS, Wang N, Subramanian M Aylwin SJ, Odia Y, et al. Targeted treatment of papillary craniopharyngiomas harboring BRAF V600E mutations. Cancer. 2019 Sep; 125(17):2910-4.

31 Bernstein A, Mrowczynski OD, Greene A, Ryan S, Chung C, Zacharia BE, et al. Dual BRAF/MEK therapy in BRAF V600E-mutated primary brain tumors: a case series showing dramatic clinical and radiographic responses and a reduction in cutaneous toxicity. J Neurosurg. 2019 Nov 1;1-6. Epub.

32 Alexandraki KI, Kaltsas GA, Karavitaki N, Grossman AB. The Medical Therapy of Craniopharyngiomas: The Way Ahead. J Clin Endocrinol Metab. 2019 Dec;104(12):5751-64.

33 Gao C, Wang Y, Broaddus R, Sun L, Xue F, Zhang W. Exon 3 mutations of CTNNB1 drive tumorigenesis: a review. Oncotarget. 2017 Nov;9(4):5492-508

34 Coy S, Rashid R, Lin JR, Du Z, Donson AM, Hankinson TC, et al. Multiplexed immunofluorescence reveals potential PD-1/PD-L1 pathway vulnerabilities in craniopharyngioma. Neuro-oncol. 2018 Jul;20(8):1101-12.
35 Kassab C, Zamler D, Kamiya-Matsuoka C, Gatalica Z, Xiu J, Spetzler D, et al. Genetic and immune profiling for potential therapeutic targets in adult human craniopharyngioma. Clin Oncol Res. 2019;2(3):2-8.

36 Vujovic S, Henderson S, Presneau N, Odell E Jacques TS, Tirabosco R, et al. Brachyury, a crucial regulator of notochordal development, is a novel biomarker for chordomas. J Pathol. 2006 Jun;209(2):157-65.

37 Presneau N, Shalaby A, Ye H, Pillay N, Halai $\mathrm{D}$, Idowu B, et al. Role of the transcription factor $\mathrm{T}$ (brachyury) in the pathogenesis of sporadic chordoma: a genetic and functionalbased study. J Pathol. 2011 Feb;223(3):327-35.

38 Miettinen M, Wang Z, Lasota J, Heery C, Schlom J, Palena C. Nuclear Brachyury Expression Is Consistent in Chordoma, Common in Germ Cell Tumors and Small Cell Carcinomas, and Rare in Other Carcinomas and Sarcomas: An Immunohistochemical Study of 5229 Cases. Am J Surg Pathol. 2015 Oct;39(10):1305-12.

39 Yang XR, Ng D, Alcorta DA, Liebsch NJ, Sheridan E, Li S, et al. T (brachyury) gene duplication confers major susceptibility to familial chordoma. Nat Genet. 2009 Nov;41(11):1176-8.

40 Amary MF, Bacsi K, Maggiani F, Damato S, Halai D, Berisha F, et al. IDH1 and IDH2 mutations are frequent events in central chondrosarcoma and central and periosteal chondromas but not in other mesenchymal tumours. J Pathol. 2011 Jul;224(3):334-43.

41 Asioli S, Zoli M, Guaraldi F, Sollini G, Bacci A, Gibertoni D, et al. Peculiar pathological, radiological and clinical features of skull-base dedifferentiated chordomas. Results from a referral centre case-series and literature review. Histopathology. 2019 Oct. https://doi.org/ 10.1111/his.14024. Epub.

42 Mobley BC, McKenney JK, Bangs CD, Callahan K, Yeom KW, Schneppenheim R, et al. Loss of SMARCB1/INI1 expression in poorly differentiated chordomas. Acta Neuropathol. 2010 Dec;120(6):745-53.

43 Hasselblatt M, Thomas C, Hovestadt V, Schrimpf D, Johann P, Bens S, et al. Poorly differentiated chordoma with SMARCB1/INI1 loss: a distinct molecular entity with dismal prognosis. Acta Neuropathol. 2016 Jul;132(1): 149-51.

44 Parwani AV, Stelow EB, Pambuccian SE, Burger PC, Ali SZ. Atypical teratoid/rhabdoid tumor of the brain: cytopathologic characteristics and differential diagnosis. Cancer. 2005 Apr;105(2):65-70.

45 Arita K, Sugiyama K, Sano T, Oka H. Atypical teratoid/rhabdoid tumour in sella turcica in an adult. Acta Neurochir (Wien). 2008 May; 150(5):491-5.

46 Moretti C, Lupoi D, Spasaro F, Chioma L, Di Giacinto P, Colicchia M, et al. Sella turcica atypical teratoid/rhabdoid tumor complicated with lung metastasis in an adult female. Clin Med Insights Case Rep. 2013 Nov;6:177-82.

47 Yamaguchi T, Suzuki S, Ishiiwa H, Shimizu K, Ueda Y. Benign notochordal cell tumors: A comparative histological study of benign noto- chordal cell tumors, classic chordomas, and notochordal vestiges of fetal intervertebral discs. Am J Surg Pathol. 2004 Jun;28(6):756-61.

48 Yamaguchi T, Imada H, Iida S, Szuhai K. Notochordal Tumors: An Update on Molecular Pathology with Therapeutic Implications. Surg Pathol Clin. 2017 Sep;10(3):637-56.

49 Usher I, Flanagan AM, Choi D. Systematic review of clinical, radiologic, and histologic features of benign notochordal cell tumors: implications for patient management. World Neurosurg. 2019 Oct;130:13-23.

50 Presneau N, Shalaby A, Idowu B, Gikas P, Cannon SR, Gout I, et al. Potential therapeutic targets for chordoma: PI3K/AKT/TSC1/TSC2/ mTOR pathway. Br J Cancer. 2009 May; 100(9):1406-14.

51 Frezza AM, Botta L, Trama A, Dei Tos AP Stacchiotti S. Chordoma: update on disease, epidemiology, biology and medical therapies. Curr Opin Oncol. 2019 Mar;31(2):114-20.

52 Tarpey PS, Behjati S, Young MD, Martincorena I, Alexandrov LB, Farndon SJ, et al. The driver landscape of sporadic chordoma. Nat Commun. 2017 Oct;8(1):890.

53 Lyne SB, Polster SP, Fidai S, Pytel P, Yamini B. Primary sellar paraganglioma: case report with literature review and immunohistochemistry resource. World Neurosurg. 2019 May; 125: 32-6.

54 Singh S, Kumar A, Mehrotra A, Rao RN, Behari S. Nonsecretory paraganglioma in cavernous sinus masquerading as meningioma. World Neurosurg. 2019 Jun;126:399-404

55 Baysal BE, Ferrell RE, Willett-Brozick JE, Lawrence EC, Myssiorek D, Bosch A, et al. Mutations in SDHD, a mitochondrial complex II gene, in hereditary paraganglioma. Science. 2000 Feb;287(5454):848-51.

56 Niemann S, Müller U. Mutations in SDHC cause autosomal dominant paraganglioma type 3. Nat Genet. 2000 Nov;26(3):268-70.

57 Astuti D, Latif F, Dallol A, Dahia PL, Douglas F, George E, et al. Gene mutations in the succinate dehydrogenase subunit SDHB cause susceptibility to familial pheochromocytoma and to familial paraganglioma. Am J Hum Genet. 2001 Jul;69(1):49-54.

58 Hao HX, Khalimonchuk O, Schraders M, Dephoure N, Bayley JP, Kunst H, et al. SDH5, a gene required for flavination of succinate dehydrogenase, is mutated in paraganglioma. Science. 2009 Aug;325(5944):1139-42.

59 Burnichon N, Brière JJ, Libé R, Vescovo L, Rivière J, Tissier F, et al. SDHA is a tumor suppressor gene causing paraganglioma. Hum Mol Genet. 2010 Aug;19(15):3011-20.

60 Neumann HP, Young WF Jr, Eng C. Pheochromocytoma and Paraganglioma. N Engl J Med. 2019 Aug;381(6):552-65.

61 van Nederveen FH, Gaal J, Favier J, Korpershoek E, Oldenburg RA, de Bruyn EM, et al. An immunohistochemical procedure to detect patients with paraganglioma and phaeochromocytoma with germline SDHB, SDHC, or SDHD gene mutations: a retrospective and prospective analysis. Lancet Oncol. 2009 Aug;10(8):764-71. 
62 Korpershoek E, Favier J, Gaal J, Burnichon N, van Gessel B, Oudijk L, et al. SDHA immunohistochemistry detects germline SDHA gene mutations in apparently sporadic paragangliomas and pheochromocytomas. J Clin Endocrinol Metab. 2011 Sep;96(9):E1472-6.

63 Fishbein L, Khare S, Wubbenhorst B, DeSloover D, D'Andrea K, Merrill S, et al. Wholeexome sequencing identifies somatic ATRX mutations in pheochromocytomas and paragangliomas. Nat Commun. 2015 Jan;6(1):6140.

64 Job S, Draskovic I, Burnichon N, Buffet A, Cros J, Lépine $\mathrm{C}$, et al. Telomerase Activation and ATRX Mutations Are Independent Risk Factors for Metastatic Pheochromocytoma and Paraganglioma. Clin Cancer Res. 2019 Jan; 25(2):760-70.

65 Gaal J, Burnichon N, Korpershoek E, Roncelin I, Bertherat J, Plouin PF, et al. Isocitrate dehydrogenase mutations are rare in pheochromocytomas and paragangliomas. J Clin Endocrinol Metab. 2010 Mar;95(3):1274-8.

66 Zhang J, Jiang J, Luo Y, Li X, Lu Z, Liu Y, et al. Molecular evaluation of a sporadic paraganglioma with concurrent IDH1 and ATRX mutations. Endocrine. 2018 Aug;61(2):216-23.

67 Bisceglia M, Galliani C, Giannatempo G, Lauriola W, Bianco M, D'angelo V, et al. Solitary fibrous tumor of the central nervous system: a 15-year literature survey of 220 cases (August 1996-July 2011). Adv Anat Pathol. 2011 Sep; 18(5):356-92.

68 Juco J, Horvath E, Smyth H, Rotondo F, Kovacs $K$. Hemangiopericytoma of the sella mimicking pituitary adenoma: case report and review of the literature. Clin Neuropathol. 2007 Nov-Dec;26(6):288-93.

69 Chmielecki J, Crago AM, Rosenberg M, O'Connor R, Walker SR, Ambrogio L, et al. Whole-exome sequencing identifies a recurrent NAB2-STAT6 fusion in solitary fibrous tumors. Nat Genet. 2013 Feb;45(2):131-2.

70 Robinson DR, Wu YM, Kalyana-Sundaram S, Cao X, Lonigro RJ, Sung YS, et al. Identification of recurrent NAB2-STAT6 gene fusions in solitary fibrous tumor by integrative sequencing. Nat Genet. 2013 Feb;45(2):180-5.

71 Schweizer L, Koelsche C, Sahm F, Piro RM, Capper D, Reuss DE, et al. Meningeal hemangiopericytoma and solitary fibrous tumors carry the NAB2-STAT6 fusion and can be diagnosed by nuclear expression of STAT6 protein. Acta Neuropathol. 2013 May;125(5):651-8.

72 Akaike K, Kurisaki-Arakawa A, Hara K, Suehara Y, Takagi T, Mitani K, et al. Distinct clinicopathological features of NAB2-STAT6 fusion gene variants in solitary fibrous tumor with emphasis on the acquisition of highly malignant potential. Hum Pathol. 2015 Mar; 46(3):347-56

73 Barthelmeß S, Geddert H, Boltze C, Moskalev EA, Bieg M, Sirbu H, et al. Solitary fibrous tumors/hemangiopericytomas with different variants of the NAB2-STAT6 gene fusion are characterized by specific histomorphology and distinct clinicopathological features. Am J Pathol. 2014 Apr;184(4):1209-18.
74 Fritchie KJ, Jin L, Rubin BP, Burger PC, Jenkins SM, Barthelmeß S, et al. NAB2-STAT6 Gene Fusion in Meningeal Hemangiopericytoma and Solitary Fibrous Tumor. J Neuropathol Exp Neurol. 2016 Mar;75(3):263-71.

75 Fritchie K, Jensch K, Moskalev EA, Caron A, Jenkins S, Link M, et al. The impact of histopathology and NAB2-STAT6 fusion subtype in classification and grading of meningeal solitary fibrous tumor/hemangiopericytoma. Acta Neuropathol. 2019 Feb;137(2):307-19.

76 Freeman JL, Oushy S, Schowinsky J, Sillau S, Youssef AS. Invasive giant cell tumor of the lateral skull base: a systematic review, meta-analysis, and case illustration. World Neurosurg. 2016 Dec;96:47-57.

77 Bertoni F, Bacchini P, Staals EL. Malignancy in giant cell tumor of bone. Cancer. 2003 May; 97(10):2520-9.

78 Zorlu F, Selek U, Soylemezoglu F, Oge K. Malignant giant cell tumor of the skull base originating from clivus and sphenoid bone. J Neurooncol. 2006 Jan;76(2):149-52.

79 Okubo T, Saito T, Mitomi H, Takagi T, Torigoe T, Suehara Y, et al. p53 mutations may be involved in malignant transformation of giant cell tumor of bone through interaction with GPX1. Virchows Arch. 2013 Jul;463(1):6777.

80 Lujic N, Sopta J, Kovacevic R, Stevanovic V, Davidovic R. Recurrence of giant cell tumour of bone: role of p53, cyclin D1, $\beta$-catenin and Ki67. Int Orthop. 2016 Nov;40(11):2393-9.

81 Behjati S, Tarpey PS, Presneau N, Scheipl S, Pillay N, Van Loo P, et al. Distinct H3F3A and H3F3B driver mutations define chondroblastoma and giant cell tumor of bone. Nat Genet. 2013 Dec;45(12):1479-82.

82 Presneau N, Baumhoer D, Behjati S, Pillay N, Tarpey P, Campbell PJ, et al. Diagnostic value of H3F3A mutations in giant cell tumour of bone compared to osteoclast-rich mimics. J Pathol Clin Res. 2015 Mar;1(2):113-23.

83 Cleven AH, Höcker S, Briaire-de Bruijn I, Szuhai K, Cleton-Jansen AM, Bovée JV. Mutation Analysis of H3F3A and H3F3B as a Diagnostic Tool for Giant Cell Tumor of Bone and Chondroblastoma. Am J Surg Pathol. 2015 Nov; 39(11):1576-83.

84 Kervarrec T, Collin C, Larousserie F, Bouvier C, Aubert S, Gomez-Brouchet A, et al. H3F3 mutation status of giant cell tumors of the bone, chondroblastomas and their mimics: a combined high resolution melting and pyrosequencing approach. Mod Pathol. 2017 Mar; 30(3):393-406.

85 Phi JH, Kim SK, Lee J, Park CK, Kim IH, Ahn HS, et al. The enigma of bifocal germ cell tumors in the suprasellar and pineal regions: synchronous lesions or metastasis? J Neurosurg Pediatr. 2013 Feb;11(2):107-14.

86 Sano K. Intracranial dysembryogenetic tumors: pathogenesis and their order of malignancy. Neurosurg Rev. 2001 Dec;24(4):162-7.

87 Oosterhuis JW, Stoop H, Honecker F, Looijenga LH. Why human extragonadal germ cell tumours occur in the midline of the body: old concepts, new perspectives. Int J Androl. 2007 Aug;30(4):256-63.

88 Lee SH, Appleby V, Jeyapalan JN, Palmer RD, Nicholson JC, Sottile V, et al. Variable methylation of the imprinted gene, SNRPN, supports a relationship between intracranial germ cell tumours and neural stem cells. J Neurooncol. 2011 Feb;101(3):419-28.

89 Tan C, Scotting PJ. Stem cell research points the way to the cell of origin for intracranial germ cell tumours. J Pathol. 2013 Jan;229(1): 4-11.

90 Poynter JN, Fonstad R, Tolar J, Spector LG, Ross JA. Incidence of intracranial germ cell tumors by race in the United States, 1992-2010. J Neurooncol. 2014 Nov;120(2):381-8.

91 Takami H, Fukuoka K, Fukushima S, Nakamura T, Mukasa A, Saito N, et al. Integrated clinical, histopathological, and molecular data analysis of 190 central nervous system germ cell tumors from the iGCT Consortium. Neuro-oncol. 2019 Dec;21(12):156577.

92 Ichimura K, Fukushima S, Totoki Y, Matsushita Y, Otsuka A, Tomiyama A, et al.; Intracranial Germ Cell Tumor Genome Analysis Consortium. Recurrent neomorphic mutations of MTOR in central nervous system and testicular germ cell tumors may be targeted for therapy. Acta Neuropathol. 2016 Jun;131(6): 889-901.

93 Zapka P, Dörner E, Dreschmann V, Sakamato N, Kristiansen G, Calaminus G, et al. Type, Frequency, and Spatial Distribution of Immune Cell Infiltrates in CNS Germinomas: Evidence for Inflammatory and Immunosuppressive Mechanisms. J Neuropathol Exp Neurol. 2018 Feb;77(2):119-27.

94 Meng X, Zhou S, Wan J. Primary lymphoma of the skull base in the Chinese: clinical, radiological, pathological, and therapeutic experience in a series of 8 patients. World Neurosurg. 2019 Mar;123:e171-9.

95 Guaraldi F, Casar-Borota O, Jaffrain-Rea M. Hypophysitis. In: Huhtaniemi I, Martini L, editors. Encyclopedia of endocrine diseases. Volume 2. 2nd ed. San Diego: Elsevier; 2018. pp. $325-38$.

96 Jones DT, Kocialkowski S, Liu L, Pearson DM, Bäcklund LM, Ichimura K, et al. Tandem duplication producing a novel oncogenic BRAF fusion gene defines the majority of pilocytic astrocytomas. Cancer Res. 2008 Nov;68(21): 8673-7.

97 Schindler G, Capper D, Meyer J, Janzarik W, Omran H, Herold-Mende C, et al. Analysis of BRAF V600E mutation in 1,320 nervous system tumors reveals high mutation frequencies in pleomorphic xanthoastrocytoma, ganglioglioma and extra-cerebellar pilocytic astrocytoma. Acta Neuropathol. 2011 Mar; 121(3): 397-405.

98 Goode B, Mondal G, Hyun M, Ruiz DG, Lin $\mathrm{YH}$, Van Ziffle J, et al. A recurrent kinase domain mutation in PRKCA defines chordoid glioma of the third ventricle. Nat Commun. 2018 Feb;9(1):810. 